\title{
INFLUENCE OF GERMINATION ON LECTIN IN LENS CULINARIS SEEDS
}

\author{
C. CuAdrado a,d , C. Burbano ${ }^{\mathrm{a}}$, É. Gelencsér ${ }^{\mathrm{b}}$, M. M. Pedrosa ${ }^{\mathrm{a}}, \mathrm{G}^{\mathrm{a}}$ AYET $^{\mathrm{a}}$, \\ M. MUZQUIZ ${ }^{a}$, A. PUSZTAI ${ }^{\mathrm{c}}$ and GY. HAJÓs ${ }^{\mathrm{b}}$ \\ ${ }^{a}$ Area de Tecnologia de Alimentos, SGIT-INIA, Aptdo. 8111, 28080 Madrid. Spain \\ ${ }^{\mathrm{b}}$ Central Food Research Institute, Budapest, Herman O. u. 15. Hungary \\ ${ }^{\mathrm{c}}$ The Rowett Research Institute, Bucksburn, Aberdeen, AB2 9SB, Scotland. UK
}

(Received: 25 October 1999; accepted: 9 March 2000)

The effect of germination conditions on the lectin of Lens culinaris var. Magda 20 seeds was studied. The seeds were germinated at $20^{\circ} \mathrm{C}$ under different conditions of watering and light and for different periods of time. The seed lectin was assayed by haemagglutination and quantified by competitive ELISA. Changes in lectin content during germination were also monitored by SDS-PAGE and immunoblotting. Haemagglutinating activity and lectin content in the seeds were not changed during the first three days regardless of the conditions of the germination. However, lectin concentration was significantly higher after six days of germination; relative lectin levels being particularly high when germination was carried out in the light and with daily watering. The results of SDS-PAGE and immunoblotting have also shown that the lectin was not degraded during the first six days of germination however, other storage-proteins were broken down by proteolysis.

Keywords: lentil; germination; lectin; ELISA; SDS-PAGE

Lentils are important source of protein and minerals in many parts of the world, both for animal and human nutrition. However, their nutritional value may be limited in part by the presence of undesirable compounds known as antinutritional factors. These factors include phytic acid, phenolic compounds, indigestible carbohydrates of the raffinose family, protease inhibitors and lectins (DESHPANDE et al., 1984). Lectins, as proteins with the ability to bind reversibly to specific sugars or glycoproteins, can bind to epithelial cells in the gut. Thus, dietary lectins can show growth inhibitory effect (PUSZTAI et al., 1997), and when isolated lentil lectins are incorporated in diets for rats there is a growth retardation and the activities of some of the key digestive enzymes are considerably reduced (JINDAL et al., 1982).

\footnotetext{
${ }^{d}$ To whom the correspondence should be addressed
} 
Germination is considered a suitable procedure to improve the nutritional value of legume seeds by reducing levels of antinutritional factors (SAVELKOUL et al., 1992; DONANGELO et al., 1995). In general, there is a parallelism between legume lectins and storage seed proteins in their biosynthesis, localisation and disappearance during germination (CHRISPEELS \& RAIKHEL, 1991). So, germination seems to be a potential process to eliminate lentil lectin (ROUGE, 1974; EL-MADHY et al., 1985). However, the extent of degradation depends on the conditions and the variety of legume (SAVELKOUL et al., 1992). Recently, we showed that various conditions of germination such as time, watering and light produce changes in saponin levels and a decrease in the phytic acid and the tannin content when the germs and the seeds were analysed as a whole (AYET et al., 1997). As a result of these findings, this work was devised with the aim to evaluate how these variables can influence the lectin content of lentils during seed germination.

\section{Materials and methods}

\subsection{Materials}

The seed material Lens culinaris var. vulgaris cultivar Magda 20 was obtained from the Instituto Agronómico Provincial, Albacete (Spain).

\subsection{Germination procedure}

The lentil seeds were germinated according to AYET and co-workers (1997). Twenty-five $\mathrm{g}$ of duplicate pre-soaked $(6 \mathrm{~h})$ seed samples were germinated at $20{ }^{\circ} \mathrm{C}$ under different time ( 3 or 6 days), watering (daily or on alternate days) and light (dark or $6 \mathrm{~h} \mathrm{day}^{-1}$ light) conditions. The loss of dry matter and hypocotyl lengths were measured at the different experimental conditions.

\subsection{Preparation of the samples}

Raw and germinated seed samples were freeze-dried and ground to pass through a 100-mesh sieve (Tecator, Cyclotec 1093). The germs and the seeds of germinated samples were ground and analysed as a whole. The samples were extracted in

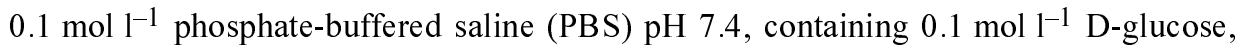
at a concentration of $200 \mathrm{mg} \mathrm{ml}^{-1}$ using an Ultraturrax homogenizer (2 min). After centrifugation ( $4300 \mathrm{~g}, 20 \mathrm{~min}, 4^{\circ} \mathrm{C}$ ) the 4- and 100-fold PBS diluted supernatants were used for haemagglutination test and ELISA quantification, respectively. 


\subsection{Haemagglutination tests}

Determinations of the haemagglutination activity were done in triplicate as described previously by GRANT (1991) using trypsin treated rat blood erythrocytes. One unit of haemagglutinating activity (HU) is defined as the amount (g) of sample in the last dilution which caused agglutination of $50 \%$ of the blood cells. Results were expressed as haemagglutination units or lectin equivalents per $\mathrm{kg}\left(\mathrm{HU} \mathrm{kg}^{-1}\right)$ of dry matter.

\subsection{Purification of lentil lectin (Lens culinaris agglutinin, $L C A$ )}

The lentil lectin was purified according to CUADRADO and co-workers (1997). Lentil meal was initially extracted with $20 \mathrm{mmol} \mathrm{l}^{-1}$ sodium acetate-acetic acid buffer, pH 5.0 (containing $0.1 \mathrm{~mol} \mathrm{l}^{-1} \mathrm{NaCl}, 0.01 \mathrm{~mol} \mathrm{l}^{-1} \mathrm{CaCl}_{2}$ and $0.5 \mathrm{mmol} \mathrm{l}^{-1} \mathrm{MnCl}_{2}$ ). The extract was precipitated with ammonium sulphate $\left(760 \mathrm{~g}^{-1}\right)$ and the sediment was extensively dialysed against water and freeze-dried (acetate extract). The residue obtained after extraction with acetate buffer was extracted with $0.05 \mathrm{~mol} \mathrm{l}^{-1}$ Tris- $\mathrm{HCl}$ buffer, pH 7.6 (also containing $0.1 \mathrm{moll}^{-1} \mathrm{NaCl}, 0.01 \mathrm{moll}^{-1} \mathrm{CaCl}_{2}$ and $0.5 \mathrm{mmol} \mathrm{l}^{-1} \mathrm{MnCl}_{2}$ ) and the supernatant was precipitated with ammonium sulphate $\left(760 \mathrm{~g} \mathrm{l}^{-1}\right)$. The sediment obtained after centrifugation was dialysed against distilled water and freeze-dried (Tris extract). The two freeze-dried extracts having haemagglutination activity (acetate extract and Tris extract) were separately dissolved in $0.05 \mathrm{~mol} \mathrm{l}^{-1}$ Tris-HCl buffer, $\mathrm{pH}$ 7.6. The extracts containing lentil lectin were purified by affinity chromatography on Sephadex G-100. The column was equilibrated and run with $0.05 \mathrm{~mol} \mathrm{l}^{-1}$ Tris- $\mathrm{HCl}$ buffer, $\mathrm{pH}$ 7.6. Elution of adsorbed lectin from the column was prepared with the same buffer containing $0.1 \mathrm{~mol} \mathrm{l}^{-1} \mathrm{D}$-glucose. Non adsorbed as well as adsorbed fractions were collected, extensively dialysed against distilled water and recovered by freeze-drying. The purification procedure was monitored by haemagglutination assay and by SDS-PAGE. The pure LCA-fraction was used as an immunogen to produce LCA specific antibody and as a standard for the ELISA or electrophoresis.

\subsection{Development of antisera to lentil lectin}

Antibody to LCA was developed in rabbits according to the method of HARBOE and INGLID (1973). Samples of LCA were dissolved in $0.01 \mathrm{~mol}^{-1}$ PBS, pH 7.4 $\left(1 \mathrm{mg} \mathrm{l}^{-1}\right)$. On days $0,14,28$ and 42 two rabbits (weight $2-2.5 \mathrm{~kg}$ ) were injected with a standard mixture of $25 \mu \mathrm{g}$ of pure immunogen per $\mathrm{kg}$ of body weight (in $50 \mathrm{ml}$ of saline and also containing $50 \mathrm{ml}$ of Freund's incomplete adjuvant) into the thicker part of the skin above the scapula. A preimmune blood sample $(20-25 \mathrm{ml})$ was taken from the marginal ear vein before the first injection. To check the antibody titer of immune sera, 
blood samples were taken 8-10 days after each booster injection. Antisera were fractionated to obtain purified IgG preparations according to the method of HARBOE and INGLID (1973).

\subsection{Competitive indirect ELISA}

Plates coated overnight at $4{ }^{\circ} \mathrm{C}$ with $0.5 \mu \mathrm{g} \mathrm{ml}^{-1} \mathrm{LCA}$ (in $0.05 \mathrm{~mol} \mathrm{l}^{-1}$ sodium carbonate-bicarbonate buffer, $\mathrm{pH} 9.8)$ were washed four times with PBST $\left(0.01 \mathrm{~mol} \mathrm{l}^{-1}\right.$ phosphate buffered saline containing $0.01 \%(\mathrm{v} / \mathrm{v})$ Tween $20, \mathrm{pH} 7.4)$. Then $0.2 \mathrm{ml}$ of PBSG $\left(0.01 \mathrm{~mol} \mathrm{l}^{-1}\right.$ PBS containing $0.5 \%$ (w/v) gelatin, $\left.\mathrm{pH} 7.4\right)$ was added and after incubation for $1 \mathrm{~h}$ at $37^{\circ} \mathrm{C}$ the plates were washed four times with PBST. After this, $0.05 \mathrm{ml}$ of standard LCA diluted in PBS containing $0.1 \mathrm{~mol} \mathrm{l}^{-1} \mathrm{D}$-glucose or lentil samples (also diluted in PBS containing D-glucose) with unknown content of lectin were added, followed by $0.05 \mathrm{ml}$ of rabbit anti-LCA IgG antibody (CFRI, Hungary, diluted 1:1000 in PBS). Determinations were performed in triplicate for each data point. After incubation for $1 \mathrm{~h}$ at $37^{\circ} \mathrm{C}$, the plates were washed four times with PBST and $0.1 \mathrm{ml}$ of biotinilated goat anti-rabbit IgG (Sigma Chem, Co, St Louis, MO USA) diluted with PBS $(1: 10000 \mathrm{v} / \mathrm{v})$ was added to each well and incubated for a further $1 \mathrm{~h}$ at $37^{\circ} \mathrm{C}$. After washing (four times) with PBST $0.1 \mathrm{ml}$ of ExtrAvidin labelled with peroxidase (Sigma Chem, Co, St Louis, MO USA) diluted with PBS (1:1000 v/v) was added to each well and incubated for further $1 \mathrm{~h}$ at $37^{\circ} \mathrm{C}$. After washing (four times) with PBST $0.1 \mathrm{ml}$ of substrate $\left(0.34 \mathrm{mg} \mathrm{ml}^{-1} o\right.$-phenylene-diamine in $0.05 \mathrm{~mol} \mathrm{l}^{-1}$ phosphate-citrate buffer, $\mathrm{pH} 5.0$ containing $0.03 \%(\mathrm{v} / \mathrm{v})$ hydrogen peroxide) was added to each well. After $5 \mathrm{~min}$, the reaction was stopped by adding $0.05 \mathrm{ml}$ of $3 \mathrm{~mol} \mathrm{l}^{-1}$ $\mathrm{H}_{2} \mathrm{SO}_{4}$ and the optical density was measured at $492 \mathrm{~nm}$ using a Dynatech (UK) plate reader. The lectin content of the samples was estimated from the calibration curve (0.001-1000 $\mu \mathrm{g} \mathrm{ml}^{-1}$ of standard LCA). Results were expressed in $\mathrm{g} \mathrm{kg}^{-1}$ of dry matter.

\subsection{SDS-PAGE gel electrophoresis and transblotting}

SDS-PAGE electrophoresis was carried out as described by HAJÓs and coworkers (1995). The total acrylamide content of running was $17.60 \%$ with $0.45 \%$ crosslinkage and that of the stacking gel was $3.95 \%$ with $1.42 \%$ cross-linkage. Samples ( $1 \mathrm{mg} 100 \mu \mathrm{l}^{-1}$ ) were incubated at $100{ }^{\circ} \mathrm{C}$ for $5 \mathrm{~min}$ in $0.01 \mathrm{~mol} \mathrm{l}^{-1}$ Tris-glycine buffer ( $\mathrm{pH} 8.3$ ) containing $3 \%(\mathrm{w} / \mathrm{v})$ SDS and $0.1 \%(\mathrm{v} / \mathrm{v}) \quad \beta$-mercaptoethanol before electrophoresis. The gels were stained with $0.5 \%(\mathrm{w} / \mathrm{v})$ Coomasie Brilliant Blue R (Sigma Chem, Co, St Louis, MO USA).

Semidry transblotting onto nitrocellulose membranes was performed according to HAJÓS and co-workers (1995). To increase the retention of small molecular weight peptides on the nitrocellulose, the membranes were processed immediately and fixed 
with $1 \%(\mathrm{v} / \mathrm{v})$ glutaraldehyde at $4{ }^{\circ} \mathrm{C}$ for $5 \mathrm{~min}$. Non-specific binding sites were blocked with TBS (0.05 mol $\mathrm{l}^{-1}$ Tris-HCI buffer saline, $\left.\mathrm{pH} 7.5\right)$ containing $2 \%(\mathrm{v} / \mathrm{v})$ Tween 20 for $5 \mathrm{~min}$, washed $3 \times 10 \mathrm{~min}$ with TBS, containing $0.05 \%$ Tween 20 , and incubated at $4{ }^{\circ} \mathrm{C}$ overnight with rabbit anti-LCA IgG antibodies (1:10). After washing the blots were incubated with biotinylated anti-rabbit IgG (1:1000; Sigma Chem, Co, St Louis, MO USA) for $2 \mathrm{~h}$. Following washing the blots were incubated with Extravidin peroxidase (1:1000; Sigma Chem, Co, St Louis, MO USA) for $1 \mathrm{~h}$. After washing, the blots were developed with substrate solution $(60 \mathrm{mg}$ of 4-chloronaphthol in $20 \mathrm{ml}$ of ethanol, $100 \mathrm{ml}$ of PBS and $40 \mu \mathrm{l}$ of $\mathrm{H}_{2} \mathrm{O}_{2}$ ) for $15 \mathrm{~min}$.

\subsection{Statistical analysis}

Analysis of variance was conducted with light, watering and germination time as factors, using BMDP-7D programme (WJ Dixson, BMDP Statistical Software, Software Release, 1990). When $\mathrm{P}$ values were $<0.05$, the significance between groups was estimated by Duncan multiple comparison's test.

\section{Results and discussion}

Germination mobilises reserve nutrients required for growth and therefore may help in the removal of some of the unwanted components of dry legumes which are thought to function as reserve nutrients (SATHE \& SALUNKHE, 1989). The germination conditions adopted in this study were selected after several trial runs in order to clearly distinguish their influence (AYET et al., 1997). A loss of dry matter was detected in all the germinated samples. With 3 day germination, the percentage of loss of dry matter ranged from $17.6 \%$ on dark and alternated watering to $24.8 \%$ on light and alternated watering. With a 6 day germination, the lowest loss of dry matter $(24.4 \%)$ was found on light and alternated watering and the highest one (35.2\%) was detected on light and daily watering. Hypocotyl length $(\mathrm{mm})$ of germinated seeds was used as an estimation of the germination progress. The mean values of the surveyed seeds with 3 day germination were $14.4 \mathrm{~mm}$ (daily watering, dark), $13.0 \mathrm{~mm}$ (daily watering, light), $14.36 \mathrm{~mm}$ (alternated watering, dark) and $11.8 \mathrm{~mm}$ (alternated watering, light). At a 6 day germination, as expected, the hypocotyl was longer and the values were $23.2 \mathrm{~mm}$ (daily watering, dark), $19.2 \mathrm{~mm}$ (daily watering, light), $27.1 \mathrm{~mm}$ (alternated watering, dark) and $22.1 \mathrm{~mm}$ (alternated watering, light). Therefore, for the same time and watering conditions, longer hypocotyls were obtained on dark than on light regime. The variance analyses showed that time, light and the watering $\times$ time interaction had significant influence on the hypocotyl length. 
Table 1 reports the data obtained for the haemagglutinating activity and lectin contents of raw and germinated lentils using haemagglutination test and ELISA, respectively. Despite the haemagglutination activity of germinated lentil seeds showing a decreasing tendency in relation to germination time, the values of this activity in germinated samples were within the range of raw lentil, even for 6 day germination on alternated watering and light. The decrease in haemagglutination activity detected could initially be due to either changes in the part of the lectin protein structure which is responsible for the sugar binding capacity and haemagglutination properties of LCA or a result of the proteolytic degradation of the lectin protein. Taking into account that haemagglutination assays are at best semi-quantitive methods to determine the presence of lectins and that the measurement of minute quantities of antinutrients require sensitive and specific methods, a more detailed study was carried out with the germinated samples. A competitive indirect ELISA technique has been developed, using specific polyclonal antibodies, to quantify the lectin concentration in lentil samples.

\section{Table 1}

Effect of germination upon haemagglutination activity (HU) and lectin concentration (LCA) of lentil seeds, measured by haemagglutination test and competitive indirect ELISA, respectively. Values are the mean of three determinations in each duplicate sample \pm standard error

\begin{tabular}{llll}
\hline $\begin{array}{c}\text { Germination } \\
\text { conditions }^{\mathrm{c}}\end{array}$ & $\begin{array}{c}\mathrm{HU}^{\mathrm{d}} \\
\left(\mathrm{g} \mathrm{kg}^{-1} \text { dry matter }\right)\end{array}$ & $\begin{array}{c}\text { LCA content } \\
\left(\mathrm{g} \mathrm{kg}^{-1} \mathrm{dry} \mathrm{matter}\right)\end{array}$ & $\begin{array}{c}\text { Proportional } \\
\text { increase in LCA } \\
\text { content }(\%)\end{array}$ \\
\hline Control & $250 \pm 80^{\mathrm{a}}$ & $0.85 \pm 0.09^{\mathrm{ab}}$ & \\
3, wd, d & $210 \pm 20^{\mathrm{a}}$ & $0.74 \pm 0.09^{\mathrm{a}}$ & \\
3, wd, 1 & $380 \pm 41^{\mathrm{a}}$ & $0.87 \pm 0.18^{\mathrm{ab}}$ & +35.3 \\
3, wa, d & $150 \pm 12^{\mathrm{a}}$ & $0.75 \pm 0.06^{\mathrm{a}}$ & +81.2 \\
3, wa, 1 & $120 \pm 10^{\mathrm{a}}$ & $0.87 \pm 0.15^{\mathrm{ab}}$ & +37.6 \\
6, wd, d & $170 \pm 13^{\mathrm{a}}$ & $1.15 \pm 0.12^{\mathrm{bc}}$ & +18.8 \\
6, wd, 1 & $170 \pm 36^{\mathrm{a}}$ & $1.54 \pm 0.18$ & $1.17 \pm 0.09^{\mathrm{c}}$ \\
6, wa, d & $170 \pm 24^{\mathrm{a}}$ & $1.01 \pm 0.009^{\mathrm{b}}$ & \\
6, wa, 1 & $125 \pm 3^{\mathrm{a}}$ & & \\
\hline
\end{tabular}

Means of the same column followed by the same superscripts are not significantly different at $5 \%$ level by t-test.

${ }^{c}$ Units: days, watering daily (wd) or alternate (wa), dark (d) or light (1).

${ }^{\mathrm{d}} \mathrm{HU}=$ Hemagglutination unit or lectin equivalent $\left(\mathrm{g} \mathrm{kg}^{-1}\right.$ of dry matter). 
The quantitative analysis by competitive ELISA revealed that the control (raw lentil) showed $0.85 \mathrm{~g} \mathrm{~kg}^{-1} \mathrm{LCA}$ content. The statistically different changes in lectin concentration (LCA) were expressed as percentage of lectin contents in germinated samples to the initial one (raw seeds). The data indicated that lectin concentration was not changed significantly during the first 3 days regardless of the condition of the germination. However, lectin concentration was significantly higher after 6 days of germination, particularly when germination was carried out in the light and with daily watering when the proportional increase in LCA content was $81 \%$. The same conditions produced the highest loss of dry matter. Our results suggest that the differences in lectin content are related to the different loss of dry matter rates produced under different germination conditions.

To non-reduction of the LCA content observed during germination in this work disagrees with those reports that lectin content decreased after germination process (ROUGE, 1974; El-MADHY et al., 1985). However, the effect of germination on the lectin content seems to depend on the genotype and environmental circumstances used in the experiment (EL-MADHY et al., 1985; SAVELKOUL et al., 1992). Our previous results, using the same lentil variety and the same germination conditions (AYET et al., 1997), indicated that germination is effective for reducing non nutritive substances as tannins and phytic acid which are present in the seeds as reserve compounds, but germination does not reduce the levels of other seed components such as saponins, which could be explained by their implication in the defense system of the plant, as suggested by FENWICK and OAKENFULL (1983).

The changes in the lentil lectin during germination were also studied by SDSpolyacrylamide gel electrophoresis and immunoblotting in order to monitor the protein structure during the germination process. Figure 1 shows the SDS-PAGE patterns of raw and germinated samples and Fig. 2 shows the immunoblotting patterns of transblotted samples after SDS-PAGE separation and video-densitometric evaluation of the bands corresponding to the lentil lectins. On the bases of the pattern related to the raw meal there was a clear evidence of the proteolysis during germination. A relative decrease was found in some bands with a molecular weight around $31 \mathrm{kD}$ (a, b and c) and a relative increase in bands between $25-18 \mathrm{kD}(\mathrm{d}$, e, and $\mathrm{f}$ ) and the appearance of new bands were observed in the lower molecular weight interval (18-8.3 kD). The loss of dry matter detected during the germination of lentil can be partially due to the proteolysis detected by electrophoresis. At the same time there was no change in the band corresponding to LCA which indicates that the lectin survived the enzymatic degradation during germination which was probed by immunoblotting patterns (Fig. 2). 


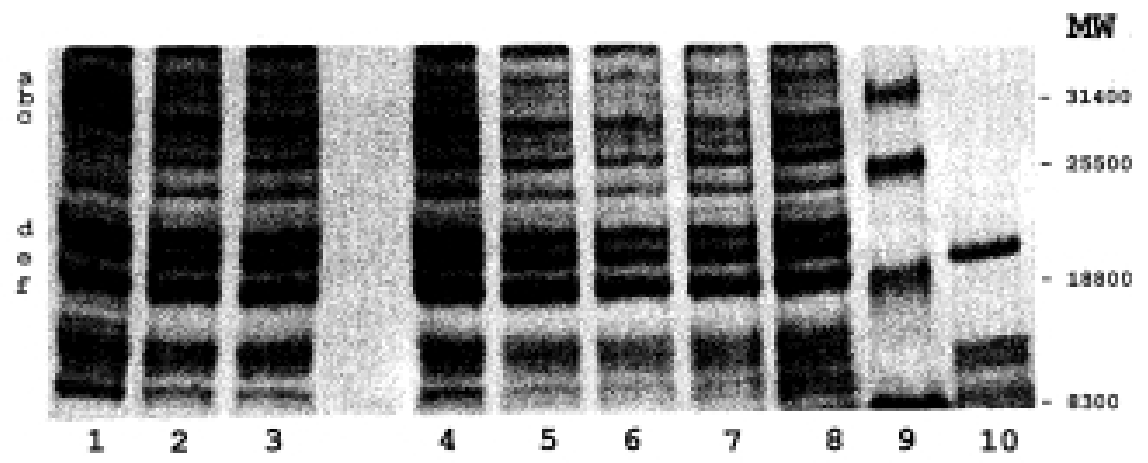

Fig. 1. SDS-PAGE patterns of raw and germinated lentil samples. (Lane 1) Raw lentil; (Lane 2) 3 days, water $/ 24 \mathrm{~h}$, dark; (Lane 3 ) 3 days, water $/ 24 \mathrm{~h}$, light; (Lane 4) 3 days, water $/ 48 \mathrm{~h}$, light; (Lane 5) 6 days, water $/ 24 \mathrm{~h}$, dark; (Lane 6) 6 days, water $/ 24 \mathrm{~h}$, light; (Lane 7) 6 days, water $/ 48 \mathrm{~h}$, dark; (Lane 8) 6 days, water/48 h, light; (Lane 9) Prestained MW (D) standards; (Lane 10) Lentil lectin standard (5 $\mu \mathrm{g}$ )
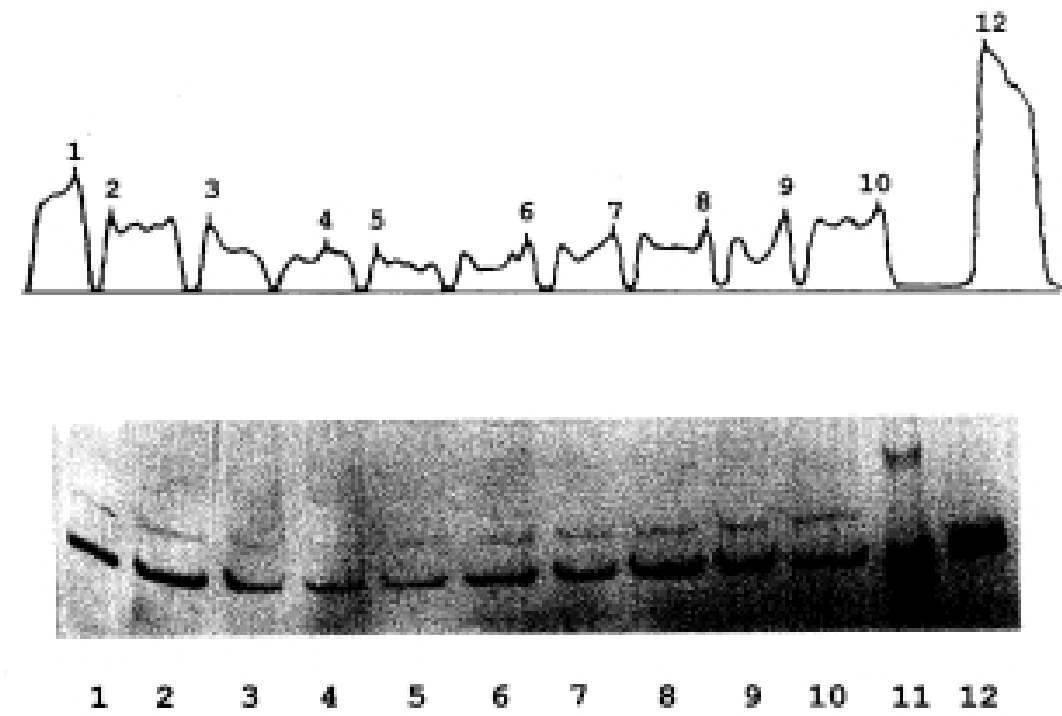

Fig. 2. Immunoblotting patterns of raw and germinated lentil samples after SDS-PAGE separation and videodensitometric evaluation of the bands corresponding to the lentil lectin. The proteins were reacted on nitrocellulose membrane with anti-lentil lectin rabbit IgG. (Lane 1) Raw lentil; (Lane 2) 3 days, water/24 h, dark; (Lane 3 ) 3 days, water $/ 24 \mathrm{~h}$, light; (Lane 4 ) 3 days, water $/ 48 \mathrm{~h}$, dark; (Lane 5 ) 3 days, water $/ 48 \mathrm{~h}$, light; (Lane 6) 6 days, water $/ 24 \mathrm{~h}$, dark; (Lane 7) 6 days, water $/ 24 \mathrm{~h}$, light; (Lane 8 ) 6 days, water/48 h, dark; (Lane 9) 6 days, water $/ 48 \mathrm{~h}$, light; (Lane 10) Raw lentil; (Lane 11) Prestained MW standards; (Lane 12) Lentil lectin standard $(5 \mu \mathrm{g})$ 


\section{Conclusions}

These findings suggested that the increase in lectin content detected is more likely to be due to higher relative content because of a decrease in the amount of other seed components than to higher absolute amount by lectin synthesis. This suggests that during lentil seed germination, under the conditions of this study, the storage proteins were enzymatically degraded, while the lentil lectin survived.

This work was supported by the INIA (Project SC97-057) and by OMFB an FM of Hungary and it is a part of COST-98 Action (EU). The authors wish to thank the INIA for awarding postdoctoral grants to C. CUADRADO and M. M. PEDROSA and EU/COST for Short Term Scientific Missions to C. CUADRADO. The highly skilled assistance of Mrs. É. KISS-VALENTIN, Mrs. B. ZÁRAI and Mr. I. MAKK is gratefully acknowledged.

\section{References}

Ayet, G. Burbano, C., CuAdrado, C., Pedrosa, M. M. Robredo, L. M., MuZquiz, M., De la CuAdrA, C., CASTAÑO A. \& OSAGIE A. (1997): Effect of germination, under different environmental conditions, on saponins, phytic acid and tannins in lentils (Lens culinaris). J. Sci. Fd Agric., 74, 273-279.

CHRISPEELS, M. J. \& RAIKHEL, N. V. (1991): Lectins, lectin genes and their role in plant defense. The Plant Cell, 3, 1-9.

CUADRADO, C., BurbanO, C., GelenCSÉR, E., GrANT, G. \& PUSZTAI, A. (1997): Large scale purification of lectin from lentil seeds and determination of the lectin content in processed lentils. -in: BARDOCZ, S., MuZQUIZ, M. \& PUSZTAI, A. (Eds) Cost 98-Effects of antinutrients on the nutritional value of legume diets. Vol. IV, Office for Official Publication of the European Communities, Luxembourg. pp. 82-88.

DeShPANDE, S. S., SATHE, S. K. \& SAlunKE, D. K. (1984): Dry beans of Phaseolus. A review. Part 3. Processing. CRC Crit, Rev. Fd Sci. Nutr., 21, 137-195.

Donangelo, C. M., Trugo, L. C., Trugo, N. M. F. \& EgGuM, B. O. (1995): Effect of germination of legume seeds on chemical composition and on protein and energy utilization in rats. Fd Chem., 53, 23-27.

EL-MADHY, A. R., MOHARRAM, Y. G. \& ABOU-SAMAHA, O. R. (1985): Influence of germination on the nutritional quality of lentil seeds. Z. Lebensmittelunters. Forsch., 181, 318-320.

FENWICK, D. E. \& OAKENFULL, D. (1983): Saponin content of food plants and some prepared foods. J. Sci. Fd Agric., 34, 186-191.

GRANT, G. (1991): Lectins. -in: D’Mello, J. P. F., DufFus C. M. \& DuFfuS, J. H. (Eds) Toxic substances in crop plants. The Royal Society of Chemistry, Cambridge. pp. 49-67.

Hajós, G., Gelencsér, E., Pusztai, A., Grant, G., SAKHRI, M. \& BARDOCZ, S. (1995): Biological effects and survival of trypsin inhibitors and the agglutinin from soybean in the small intestine of the rat. J. agric. Fd Chem., 43, 165-170. 
HARBOE, N. \& INGLID, A. (1973): Immunization, isolation of immunoglobulins, estimation of antibody titre. -in: AXELSEN, N. H., KROLL, J. \& WEEKE, B. (Eds). A manual of quantitative immunoelectrophoresis, methods and applications. Scand. J. Immunologie, Supp1 1, 1590-1595.

JINDAL, S., SONI, G. L. \& SINGH, R. (1982): Effect of feeding of lectins from lentils and peas on the intestinal and hepatic enzymes of albino rats. J. Plant Foods, 4, 95-103.

Pusztai, A., GelencSÉr, E., GRANT, G. \& BARDOCZ, S. (1997): Nutritional manipulation of immune competence in young non-ruminant animals. -in: GARNSWORLHY P. C. \& WISAMAN, G. (Eds) Recent advances in animal nutrition. Nottingham University Press, Nottingham, pp. 29-43.

ROUGE, P. (1974): Etude de la phytohémagglutinine des graines de Lentille au cours de la germination et des premiers stades du développement de la plante. I. Evolution dans les cotylédons. Compt. Rend. Acad. Sci., 278, 449-452.

SATHE, S. K. \& SALUNKHE, D. K. (1989): Technology of removal of unwanted components of dry legumes. -in: SALUNKHE, D. K. \& KADAM, S. S. (Eds) Handbook of world food legumes nutritional chemistry processing technology and utilization. Vol. III, CRC Press, Boca Raton, Florida, pp. 249-270.

SAVelKOUL, F. H. M. G., VAN DER POEL, A. F. B. \& TAMMINGA, S. (1992): The presence and inactivation of trypsin inhibitors, tannins, lectins and amylase inhibitors in legume seeds during germination. A review. Plant Food for Human Nutrition, 42, 71-85. 